\title{
Berberine induces apoptosis via ROS generation in PANC-1 and MIA-PaCa2 pancreatic cell lines
}

\author{
S.H. Park ${ }^{1}$, J.H. Sung ${ }^{2}$, E.J. Kim ${ }^{3}$ and N. Chung ${ }^{1}$ \\ ${ }^{1}$ Division of Biotechnology, College of Life Sciences and Biotechnology, Korea University, Seoul, Korea \\ ${ }^{2}$ Biomedical Research Institute, Seoul National University Hospital, Seoul, Korea \\ ${ }^{3}$ Department of Clinical Laboratory Science, Ansan University, Ansan, Korea
}

\begin{abstract}
Pancreatic cancer is the fourth leading cause of cancer death. Gemcitabine is widely used as a chemotherapeutic agent for the treatment of pancreatic cancer, but the prognosis is still poor. Berberine, an isoquinoline alkaloid extracted from a variety of natural herbs, possesses a variety of pharmacological properties including anticancer effects. In this study, we investigated the anticancer effects of berberine and compared its use with that of gemcitabine in the pancreatic cancer cell lines PANC-1 and MIA-PaCa2. Berberine inhibited cell growth in a dose-dependent manner by inducing cell cycle arrest and apoptosis. After berberine treatment, the G1 phase of PANC-1 cells increased by $10 \%$ compared to control cells, and the G1 phase of MIA-PaCa2 cells was increased by $2 \%$. Whereas gemcitabine exerts antiproliferation effects through S-phase arrest, our results showed that berberine inhibited proliferation by inducing G1-phase arrest. Berberine-induced apoptosis of PANC-1 and MIA-PaCa2 cells increased by 7 and $2 \%$ compared to control cells, respectively. Notably, berberine had a greater apoptotic effect in PANC-1 cells than gemcitabine. Upon treatment of PANC-1 and MIA-PaCa2 with berberine at a half-maximal inhibitory concentration (IC 50$)$, apoptosis was induced by a mechanism that involved the production of reactive oxygen species (ROS) rather than caspase 3/7 activation. Our findings showed that berberine had anti-cancer effects and may be an effective drug for pancreatic cancer chemotherapy.
\end{abstract}

Key words: Pancreatic cancer; Berberine; Gemcitabine; Apoptosis; Cell cycle arrest

\section{Introduction}

Pancreatic cancer is the fourth leading cause of cancer death and is responsible for $6 \%$ of all cancer-related deaths worldwide $(1,2)$. Pancreatic cancer is difficult to diagnose in its early stages and generally has a poor prognosis. For all stages combined, the relative 1- and 5-year survival rates for pancreatic cancer are approximately $25 \%$ and $6 \%$, respectively $(1,2)$. Gemcitabine is the standard treatment after cancer surgery, but the response rate is $<20 \%(3-5)$. Thus, the identification of new drugs and the development of improved therapeutic strategies for pancreatic cancer are essential.

Berberine is an isoquinoline alkaloid isolated from a variety of natural herbs such as berberis (Berberis aquifolium, B. vulgaris, and B. aristata), Hydrastis canadensis, Phellodendron amurense, Coptis chinensis, and Tinospora cordifolia (6-8). Berberine is usually found in bark, stems, rhizomes, and roots and has long been used as both a dye and a medicinal herb in Indian Ayurvedic, Unani (9), and Chinese medicine (10). A large number of studies have shown that berberine possesses a variety of biochemical and pharmacological properties including antibacterial, antihypertensive, anti-inflammatory, antidiabetic, and antioxidative effects (10). Berberine is also known to possess anticancer properties, and it has been reported (10) that these may vary depending on cell type. In this study, we investigated the growth-inhibitory effect of berberine on PANC-1 and MIAPaCa2 pancreatic cancer cells and found that it affected cell cycle progression and apoptosis. We also observed that berberine induced the generation of reactive oxygen species (ROS), which ultimately facilitated apoptosis. Additionally, we compared the anticancer effects of gemcitabine and berberine by evaluating cellular growth, cell cycle, and apoptosis in two pancreatic cancer cell lines.

\section{Material and Methods}

\section{Cell culture}

The human pancreatic cancer cell lines PANC-1 and MIA-PaCa2 were obtained from American Type Culture

Correspondence: Namhyun Chung: <nchung@korea.ac.kr>.

Received August 5, 2014. Accepted September 26, 2014. First published online December 12, 2014. 

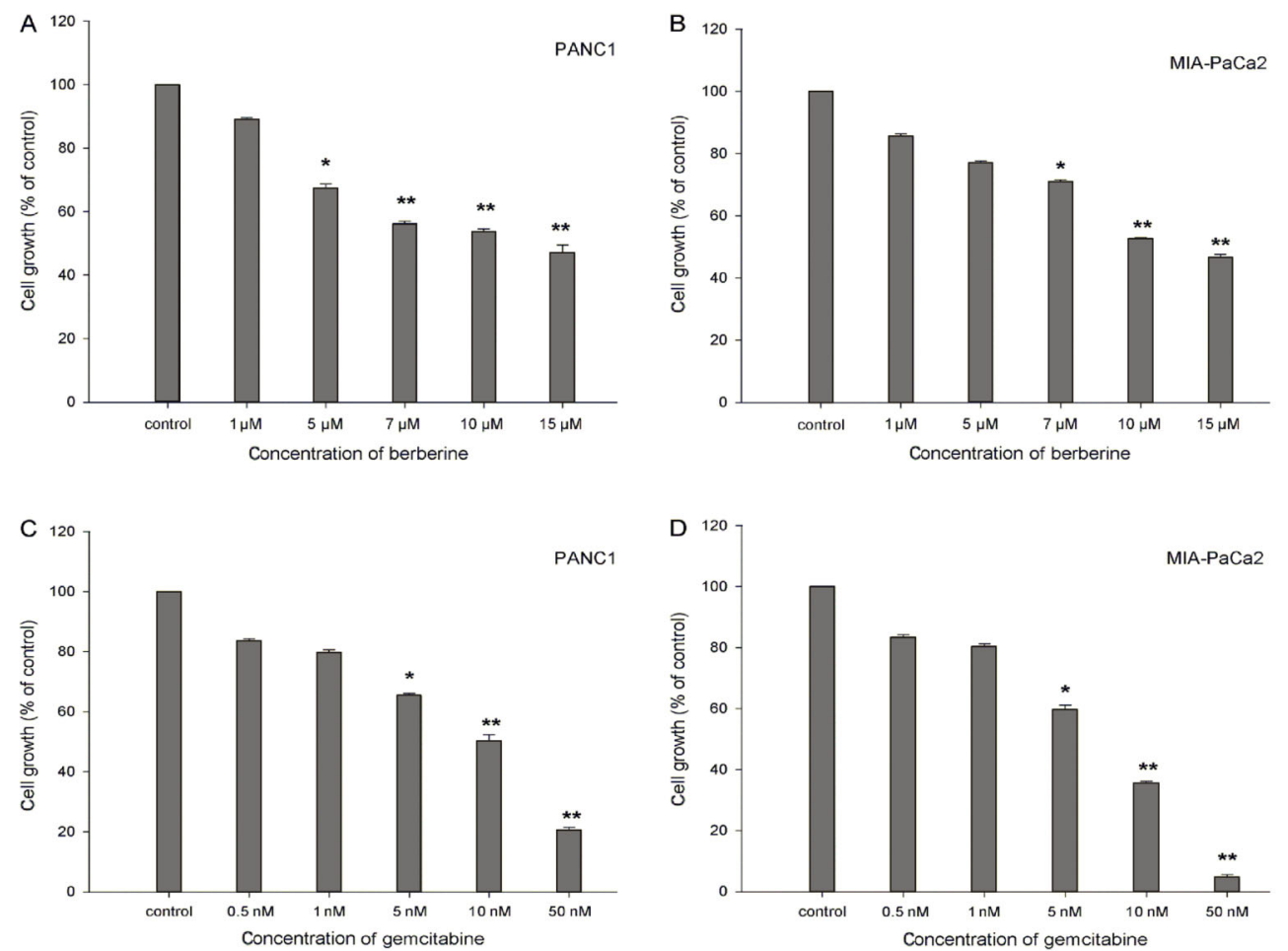

Figure 1. Cell growth rate after treatment of PANC-1 $(A, C)$ or MIA-PaCa2 $(B, D)$ pancreatic cancer cell lines with berberine or gemcitabine. The cells were treated with distilled water (control), berberine $(A, B ; 1,5,7,10$, or $15 \mu \mathrm{M})$ or gemcitabine $(C, D ; 0.5,1,5$, 10 , or $50 \mathrm{nM}$ ) for $72 \mathrm{~h}$. Growth rate was calculated by trypan blue dye exclusion. Data showed relative cell survival rate as the percentage vs that of control cells after berberine or gemcitabine treatment. ${ }^{*} \mathrm{P}<0.05,{ }^{*} \mathrm{P}<0.01$ versus control (Student's $t$-test).

Collection (USA). They were cultured in Dulbecco's modified Eagle's medium (DMEM) supplemented with $10 \%$ fetal bovine serum, $100 \mathrm{U} / \mathrm{mL}$ penicillin, and $100 \mathrm{mg} /$ $\mathrm{mL}$ streptomycin (Gibco, USA). All cells were maintained at $37^{\circ} \mathrm{C}$ in humidified air with $5 \% \mathrm{CO}_{2}$.

\section{Treatment with gemcitabine and berberine}

PANC-1 and MIA-PaCa2 cells were seeded at a density of $5 \times 10^{5}$ cells. Cells were incubated for $72 \mathrm{~h}$ with media containing $10 \mathrm{nM}$ gemcitabine or $15 \mu \mathrm{M}$ berberine for PANC-1, and $7 \mathrm{nM}$ gemcitabine or $10 \mu \mathrm{M}$ berberine for MIA-PaCa2. Cell viability was determined with trypan blue dye exclusion assays. Data analyses for halfmaximal inhibitory concentration $\left(\mathrm{IC}_{50}\right)$ were performed using Microsoft Excel 2010 (Microsoft Inc., USA).

\section{Cell cycle analysis}

Cells were collected by treatment with trypsin-EDTA, washed twice with phosphate-buffered saline (PBS), and fixed for at least $4 \mathrm{~h}$ by adding ice-cold $70 \%$ ethanol $\left(-20^{\circ} \mathrm{C}\right)$. The ethanol was subsequently removed after centrifugation at $500 \mathrm{~g}$ for $5 \mathrm{~min}$, and then cells were washed with PBS and resuspended in PBS. Propidium iodide $(\mathrm{PI})$ staining solution containing $\mathrm{PI}(50 \mu \mathrm{L} / \mathrm{mL}$ in PBS; Sigma-Aldrich, USA), RNase (1 mg/mL in PBS,
Sigma-Aldrich), and Triton X-100 was added to a fluorescence-activated cell sorting (FACS) tube in the dark at room temperature. The cell cycle was analyzed by flow cytometry using a FACSCalibur system (BD Biosciences, USA) at excitation/emission wavelengths of $488 / 617 \mathrm{~nm}$, respectively, and all experiments were performed in triplicate.

\section{Cell apoptosis assay}

The percentage of apoptotic cells was analyzed by flow cytometry using an Annexin $V$ assay kit (BD Biosciences) following the manufacturer's instructions. Briefly, after treatment, cells were harvested with trypsinEDTA and washed twice in PBS. Cells were then resuspended in $100 \mu \mathrm{L}$ binding buffer, to which $5 \mu \mathrm{L}$ annexin V-fluorescein isothiocyanate (FITC) and $5 \mu \mathrm{L} \mathrm{PI}$ were added, and then incubated at room temperature for $15 \mathrm{~min}$ in the dark. After incubation, $400 \mu \mathrm{L}$ binding buffer was added, and the percentage of apoptotic cells was analyzed by flow cytometry using a FACSCalibur system.

\section{Caspase 3/7 assay}

Cells were seeded in white 96-well plates at densities of $2.5 \times 10^{3}, 5 \times 10^{3}$, and $1 \times 10^{4}$ cells. Cells were then treated with berberine or gemcitabine, and after 24,48 , or $72 \mathrm{~h}$, 

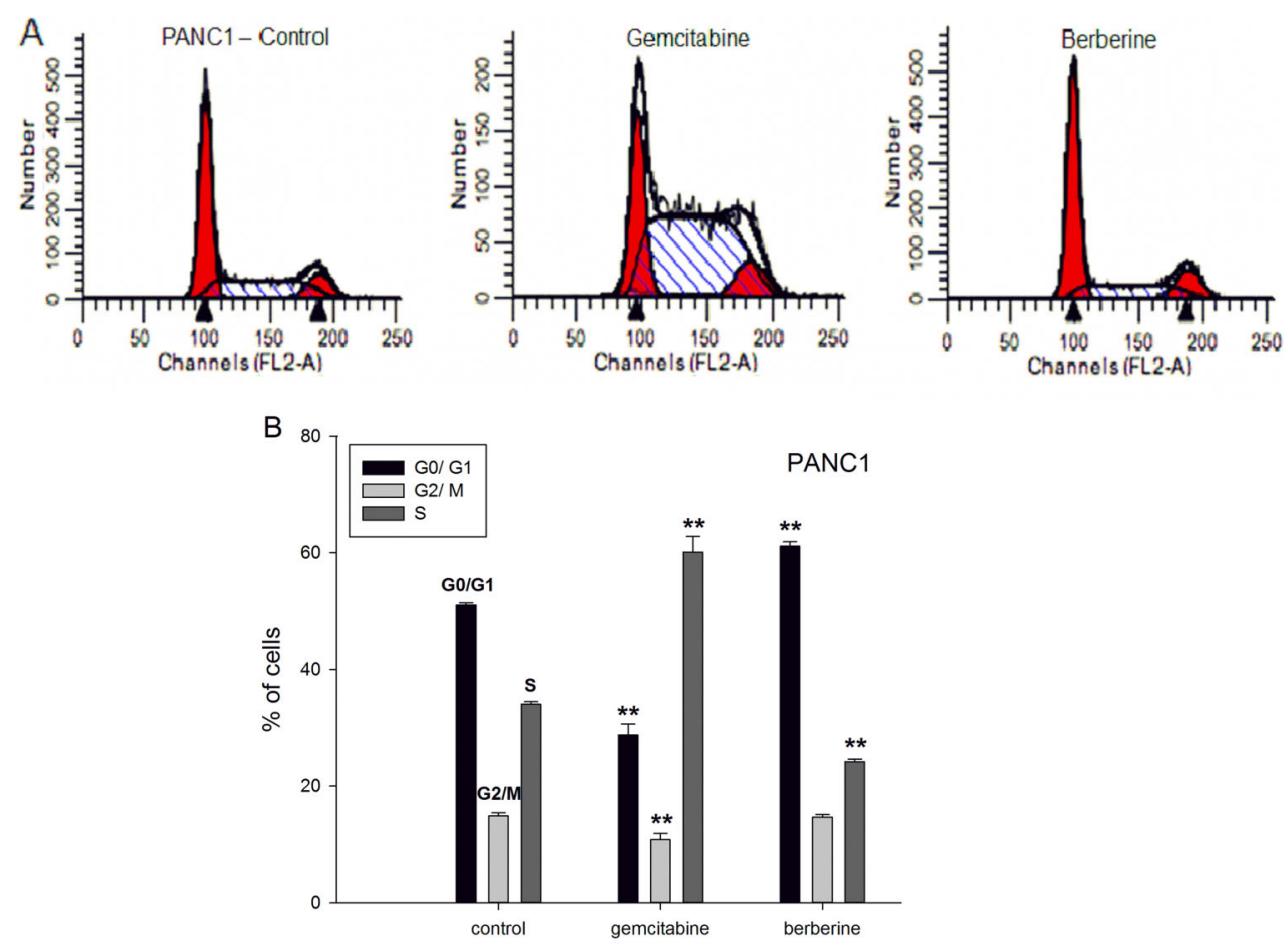

Figure 2. Cell cycle distribution after treatment of PANC-1 with berberine or gemcitabine. PANC-1 cells were treated with distilled water (control), $15 \mu \mathrm{M}$ berberine, or $10 \mathrm{nM}$ gemcitabine for $72 \mathrm{~h}$. The cell cycle distribution was analyzed by the ModFit LT software and depicted using histograms $(A)$ and bar plots $(B)$. Cell cycle was analyzed as the percentage of cells at each stage of the cell cycle after DNA staining with PI. Data from a representative experiment (from a total of at least three) are shown. ${ }^{*} \mathrm{P}<0.01$ versus controls (Student's $t$-test).

caspase 3/7 activities were measured with Caspase-Glo $3 / 7$ assay (Promega, USA) following the manufacturer's instructions. The caspase $3 / 7$ activity of berberine- and gemcitabine-treated cells was calculated as caspase activity relative to that in untreated cells.

\section{Measurement of ROS}

Intracellular ROS levels were determined by measuring the oxidative conversion of cell-permeable $2^{\prime}, 7^{\prime}$ dichlorofluorescein diacetate (DCFH-DA, Sigma-Aldrich) to fluorescent dichlorofluorescein (DCF) using a multilabel plate reader (Victor3, Perkin Elmer, USA). Cells were treated with berberine or gemcitabine for 24,48 , or $72 \mathrm{~h}$. The cells were washed with PBS and incubated with DCFH-DA at $37^{\circ} \mathrm{C}$ for $30 \mathrm{~min}$. Then, DCF fluorescence distribution was detected by fluorospectrophotometric analysis at an excitation wavelength of $488 \mathrm{~nm}$ and an emission wavelength of $535 \mathrm{~nm}$. The fluorescence intensity was normalized according to the number of cells.

\section{Statistical analysis}

Statistical significance was determined with $t$-tests using the SPSS software (version 20, IBM Corp., USA). Data are reported as the mean $\pm S D$ of at least three independent experiments. $\mathrm{P}<0.05$ was considered to be statistically significant.

\section{Results}

\section{Growth rate after treatment}

In order to determine the effect of berberine on cell growth, PANC-1 and MIA-PaCa2 were treated with 1$15 \mu \mathrm{M}$ berberine for $72 \mathrm{~h}$. As shown in Figure $1 \mathrm{~A}$ and $\mathrm{B}$, berberine treatment inhibited cell growth dose-dependently in both PANC-1 and MIA-PaCa2 cells. Treatment with 5-15 $\mu \mathrm{M}$ (PANC-1) and 1-15 $\mu \mathrm{M}$ (MIA-PaCa2) berberine significantly reduced cell viability. The $I_{50}$ values of berberine were approximately 15 and $10 \mu \mathrm{M}$ for PANC-1 and MIA-PaCa2, respectively.

The growth-inhibitory effects of gemcitabine for PANC-1 and MIA-PaCa2 were determined. Gemcitabine inhibited growth in a dose-dependent manner. The $I_{50}$ values were calculated as approximately 10 and $7 \mathrm{nM}$ for PANC-1 and MIA-PaCa2, respectively (Figure $1 \mathrm{C}$ and D).

\section{Cell cycle profiles after treatment}

Cell cycle progression was examined after treatment with berberine. As shown in Figure 2, treatment of 

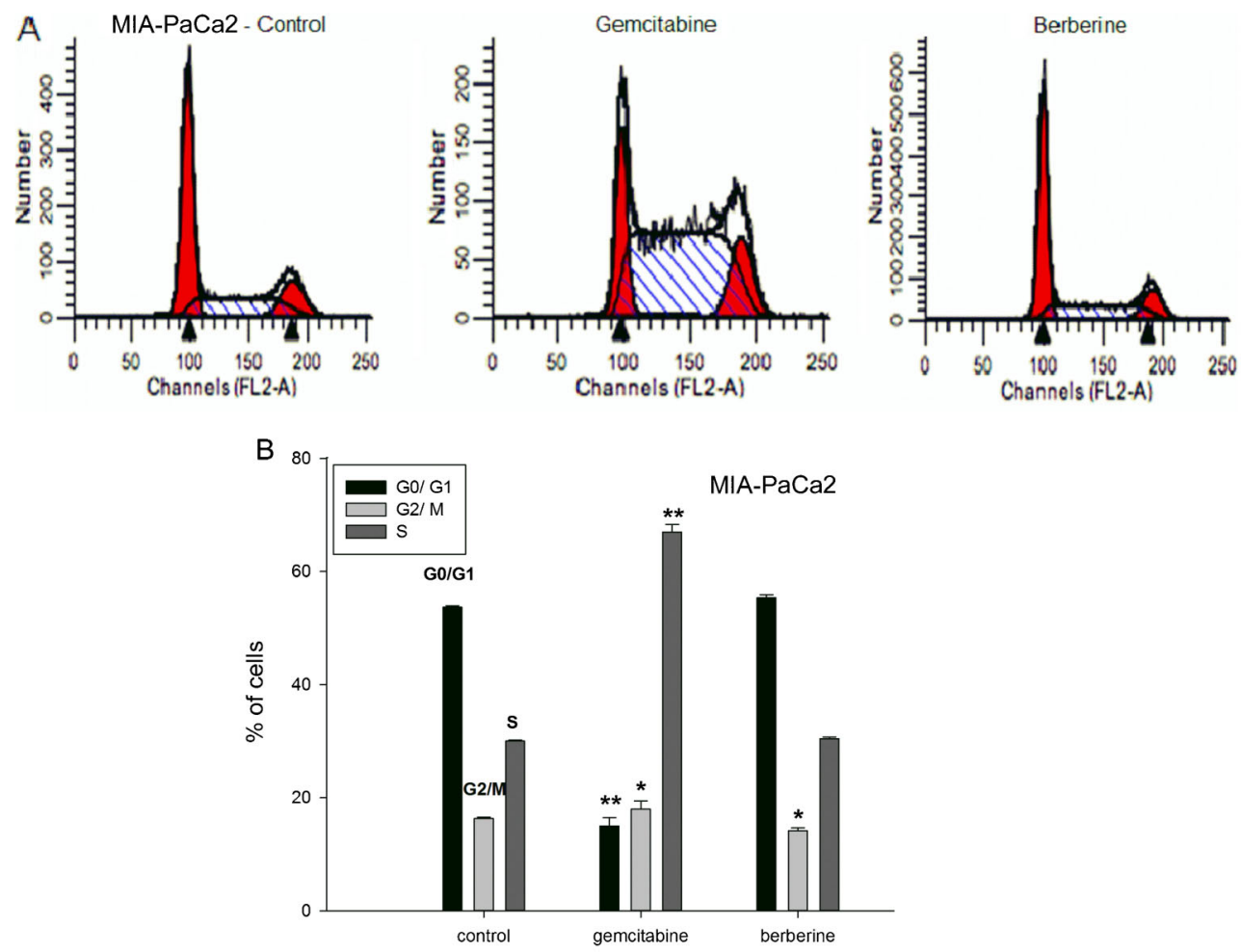

Figure 3. Cell cycle after treatment of MIA-PaCa2 with berberine or gemcitabine. MIA-PaCa2 cells were treated with distilled water (control), $10 \mu \mathrm{M}$ berberine, or $7 \mathrm{nM}$ gemcitabine for $72 \mathrm{~h}$. The cell cycle distribution was analyzed by the ModFit LT software and depicted using histograms $(A)$ and bar plots $(B)$. Cell cycle was analyzed as the percentage of cells at each stage of the cell cycle after DNA staining with PI. Data from a representative experiment (from a total of at least three) are shown. ${ }^{*} P<0.05,{ }^{* *} P<0.01$ versus control (Student's $t$-test).

PANC-1 cells with $15 \mu \mathrm{M}$ berberine for $72 \mathrm{~h}$ resulted in a significantly higher percentage $(61.1 \pm 1.7 \%)$ of cells in the $\mathrm{G} 1$ phase than in the control group $(51.1 \pm 0.8 \%)$, with a corresponding reduction in the percentage of cells in the $\mathrm{S}$ phase. Similar results were obtained for MIA-PaCa2 $(55.4 \pm 1.1 \%)$ when treated with $10 \mu \mathrm{M}$ berberine for $72 \mathrm{~h}$ compared to the control group (53.7 $\pm 0.5 \%)$ (Figure 3). These data suggest that inhibition of cell proliferation or induction of cell death in pancreatic cancer cells by berberine is associated with the induction of G1 arrest.

In comparison, Figure 2 shows that treatment of PANC-1 cells with gemcitabine increased the percentage of cells in $S$ phase to $60.1 \pm 6.0 \%$ and reduced the percentage in the G0/G1 phase to $28.7 \pm 4.2 \%$. Gemcitabine-treated MIA-PaCa2 cells had $67.0 \pm 2.7 \%$ cells in S phase compared to only $30.0 \pm 0.4 \%$ in the control cells (Figure 3 ). These data suggest that gemcitabine inhibited pancreatic cancer cell proliferation by inducing S-phase cell cycle arrest.

\section{Cell apoptosis after treatment}

To investigate the apoptotic effect of berberine, PANC1 and MIA-PaCa2 cells were treated with berberine for $72 \mathrm{~h}$, and apoptotic cells were assessed by staining with annexin V and PI. Early apoptotic cells are shown in the lower-right quadrant of the scatter plot, and live cells are in the lower-left quadrant (Figure 4). Berberine-induced apoptosis of PANC-1 cells increased by $12.2 \pm 1.6 \%$ compared to $5.0 \pm 1.1 \%$ in control cells (Figure $4 \mathrm{C}$ ). Apoptosis of MIA-PaCa2 cells increased $5.7 \pm 0.3 \%$ compared to $2.8 \pm 1.1 \%$ in control cells (Figure 4D). These results showed that berberine induced cell death through apoptosis in both pancreatic cancer cell lines.

Gemcitabine-induced apoptosis of PANC-1 cells was increased to $8.6 \pm 2.1 \%$ compared to control cells $(5.0 \pm 1.1 \%)$, and apoptosis of MIA-PaCa2 cells was increased to $6.2 \pm 1.7 \%$ compared to control cells $(2.8 \pm 1.1 \%)$ (Figure $4 \mathrm{C}$ and $\mathrm{D})$. The results suggest that the relative apoptosis efficacy of berberine in MIA-PaCa2 cells is roughly equivalent to that of gemcitabine. However, berberine induced more apoptosis in PANC-1 cells than did gemcitabine.

\section{Caspase 3/7 activity after treatment}

To determine whether apoptosis after treatment with berberine or gemcitabine was caspase 3/7-dependent, PANC-1 cells were treated with $I_{50}$ values of $15 \mu \mathrm{M}$ berberine and $10 \mathrm{nM}$ gemcitabine. MIA-PaCa2 cells were 
A
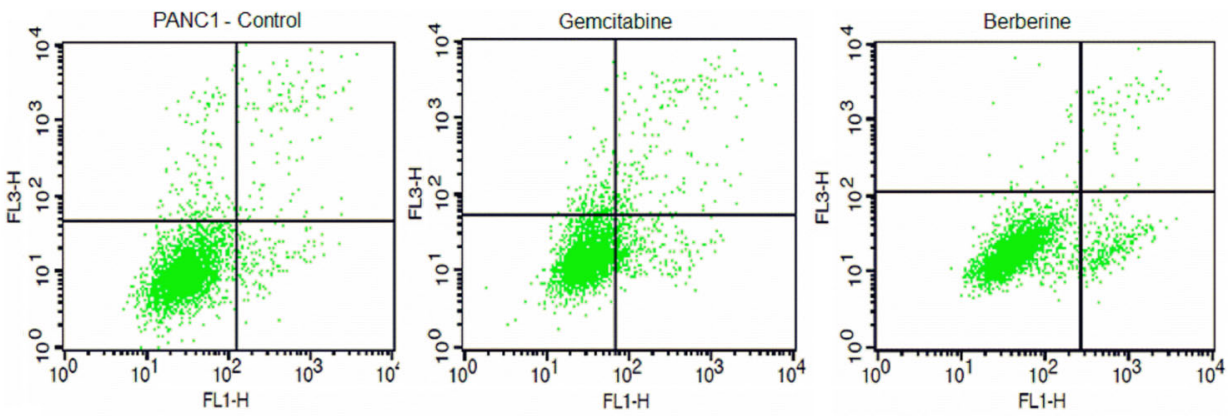

B
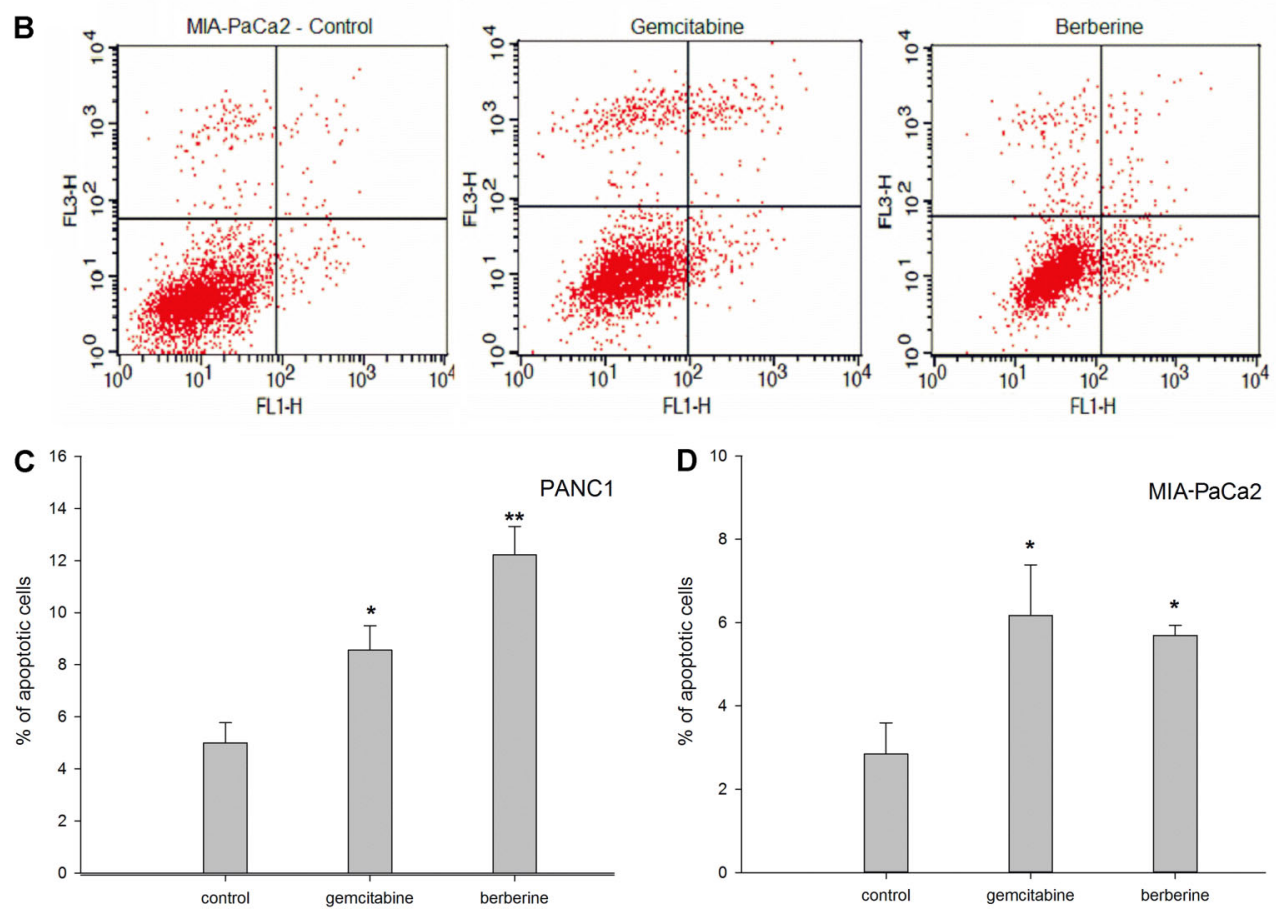

Figure 4. Annexin $V$ staining after treatment with berberine and gemcitabine. A, PANC-1 cells were treated with distilled water (control), $15 \mu \mathrm{M}$ berberine, or $10 \mathrm{nM}$ gemcitabine for $72 \mathrm{~h}$. B, MIA-PaCa2 cells were treated with distilled water, $10 \mu \mathrm{M}$ berberine, or $7 \mathrm{nM}$ gemcitabine for $72 \mathrm{~h}$. C, PANC-1 cells were treated with distilled water, $15 \mu \mathrm{M}$ berberine, or $10 \mathrm{nM}$ gemcitabine for $72 \mathrm{~h}$. $D$, MIA$\mathrm{PaCa} 2$ cells were treated with distilled water, $10 \mu \mathrm{M}$ berberine, or $7 \mathrm{nM}$ gemcitabine for $72 \mathrm{~h}$. All cells were stained with FITCconjugated annexin $\mathrm{V}$ in a buffer containing $\mathrm{PI}$ and analyzed by flow cytometry. Data are reported as means $\pm \mathrm{SD}$ from a representative experiment (from a total of at least three). ${ }^{*} \mathrm{P}<0.05$, ${ }^{*} \mathrm{P}<0.01$ versus control (Student's $t$-test).

also treated with $\mathrm{IC}_{50}$ values of $10 \mu \mathrm{M}$ berberine and $7 \mathrm{nM}$ gemcitabine for $72 \mathrm{~h}$. There was no change in relative caspase $3 / 7$ activity, suggesting that the apoptosis was caspase 3/7-independent with $\mathrm{IC}_{50}$ concentrations of berberine and gemcitabine. Figure $5 \mathrm{~A}$ shows that when treated with $10,50,100$, or $200 \mu \mathrm{M}$ berberine, PANC-1 and MIA-PaCa2 cells did not show significant caspase 3/7 activation compared to untreated cells. However, caspase 3/7 activity for PANC-1 cells gradually increased with higher concentrations of gemcitabine. When the gemcitabine concentration was increased from 10 to $50 \mathrm{nM}$ for a $72-\mathrm{h}$ treatment period, caspase $3 / 7$ activity for MIA$\mathrm{PaCa} 2$ increased abruptly and then gradually decreased with further increases in gemcitabine concentration (Figure 5B). To better explain this phenomenon, the relative activity was examined over time with varying concentrations of the chemicals. In the case of gemcitabine, the relative activity with PANC-1 increased gradually with time up to $72 \mathrm{~h}$ (Figure 6A). With increasing concentrations of berberine, activity peaked at $48 \mathrm{~h}$ and decreased at $72 \mathrm{~h}$ (Figure 6B). The relative activity with MIA-PaCa2 was also examined. In the case of gemcitabine, activity gradually increased up to $72 \mathrm{~h}$. However, in the case of berberine, activity was highest at $24 \mathrm{~h}$ and decreased with time (Figure 7). Collectively, these data indicate that the apoptotic response with berberine was 

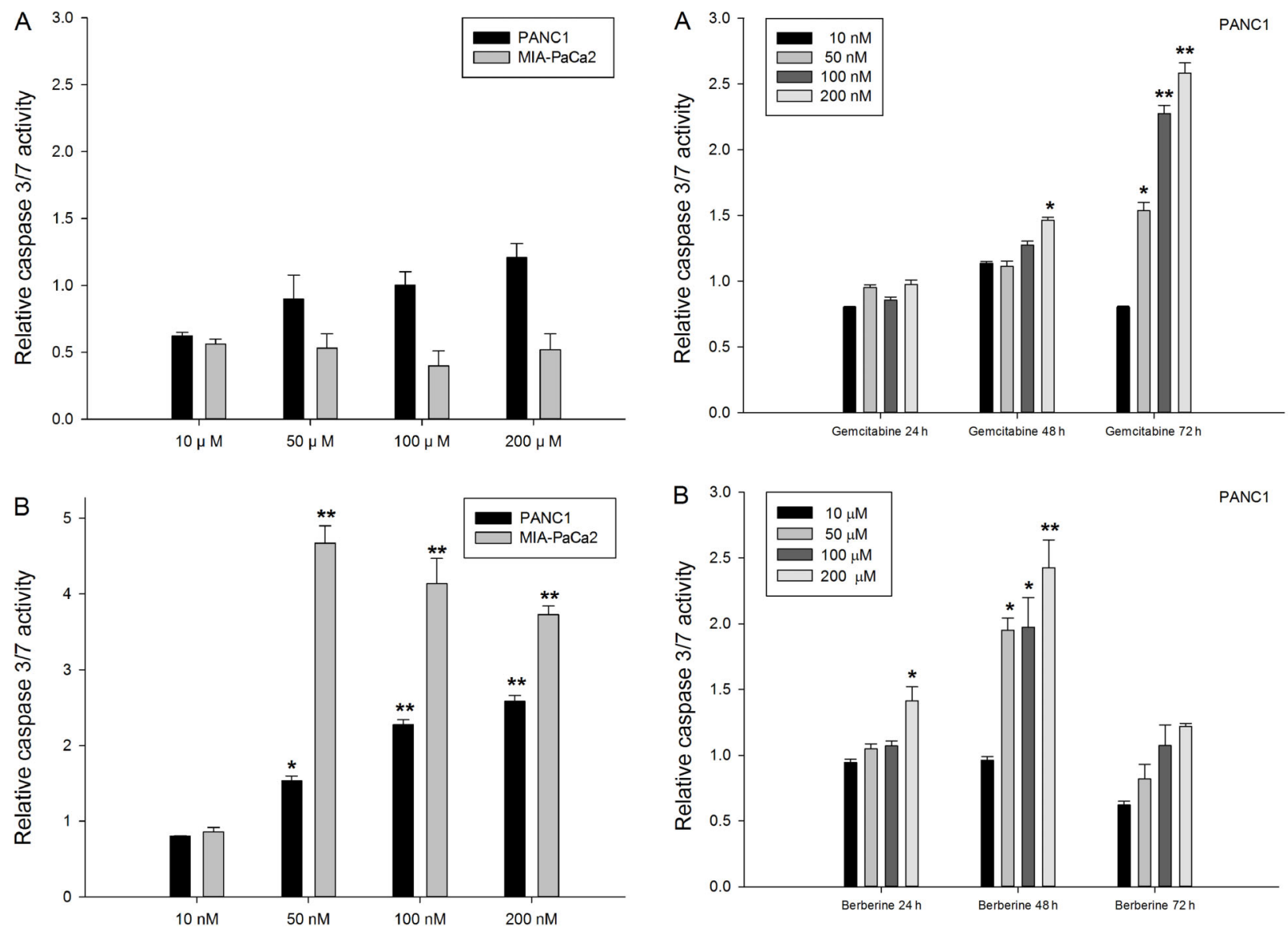

Figure 5. Caspase $3 / 7$ activity analyse of PANC-1 and MIA$\mathrm{PaCa} 2$ cells after $72-\mathrm{h}$ treatment with berberine $(A)$ and with gemcitabine $(B)$. Data are reported as mean activity $(n \geqslant 3)$ relative to control $\pm \mathrm{SD}$. ${ }^{*} \mathrm{P}<0.05,{ }^{* *} \mathrm{P}<0.01$ versus control (Student's $t$-test).

much quicker in both cell lines, but especially in MIA$\mathrm{PaCa} 2$. This result also indicates that the apoptotic response induced by caspase $3 / 7$ activity should be assessed at many time points; a single measurement is not sufficient.

Following gemcitabine treatment (Figure 5B), pancreatic cancer cells did not show significant caspase $3 / 7$ activation at a lower concentration of gemcitabine (10 nM) for $72 \mathrm{~h}$. However, at higher concentrations ( $\geqslant 50 \mathrm{nM})$ PANC-1 cells exhibited higher caspase $3 / 7$ activation, but to a lower extent than observed for MIA-PaCa2. On the other hand, PANC-1 treated with berberine for $48 \mathrm{~h}$ showed higher overall caspase $3 / 7$ activation than MIA$\mathrm{PaCa} 2$ treated with berberine for $24 \mathrm{~h}$ (Figures $6 \mathrm{~B}$ and $7 \mathrm{~B}$ ). These results suggest that caspase $3 / 7$ was activated earlier by berberine than by gemcitabine, and that the mechanism for cell death was caspase 3/7-independent at a lower berberine concentration $\left(\mathrm{IC}_{50}\right)$. The results in

Figure 6. $A$, Caspase $3 / 7$ activities after treatment of PANC1 cells with gemcitabine $(A)$ and with berberine $(B)$ for 24,48 , and $72 \mathrm{~h}$. Data are reported as means \pm SD activity $(n \geqslant 3)$ relative to control. ${ }^{*} \mathrm{P}<0.05,{ }^{* *} \mathrm{P}<0.01$ versus control (Student's t-test).

Figures 6 and 7 also suggest that the cell death mechanism is caspase 3/7-dependent at high concentrations of both berberine $(\geqslant 50 \mu \mathrm{M})$ and gemcitabine $(\geqslant 50 \mathrm{nM})$.

\section{Intracellular ROS levels after treatment}

We determined the effect of ROS generation induced by berberine or gemcitabine in PANC-1 and MIA-PaCa2 cells. ROS production in PANC-1 cells incubated with $10 \mathrm{nM}$ gemcitabine or $10 \mu \mathrm{M}$ berberine for $72 \mathrm{~h}$ was nearly 4 times that of control cells (Figure 8). ROS production in PANC-1 cells was dose dependent. For MIA-PaCa2 cells treated with $10 \mathrm{nM}$ gemcitabine for $72 \mathrm{~h}$, ROS production increased approximately 2.7 -fold. In cells treated with $10 \mu \mathrm{M}$ berberine, ROS production increased 2.6-fold relative to control cells (data not shown). The proportion of ROS production in MIA-PaCa2 cells was also dose dependent. Our results showed that treatment with both gemcitabine and berberine for $72 \mathrm{~h}$ significantly increased ROS levels in a dose-dependent manner. The phenomenon 

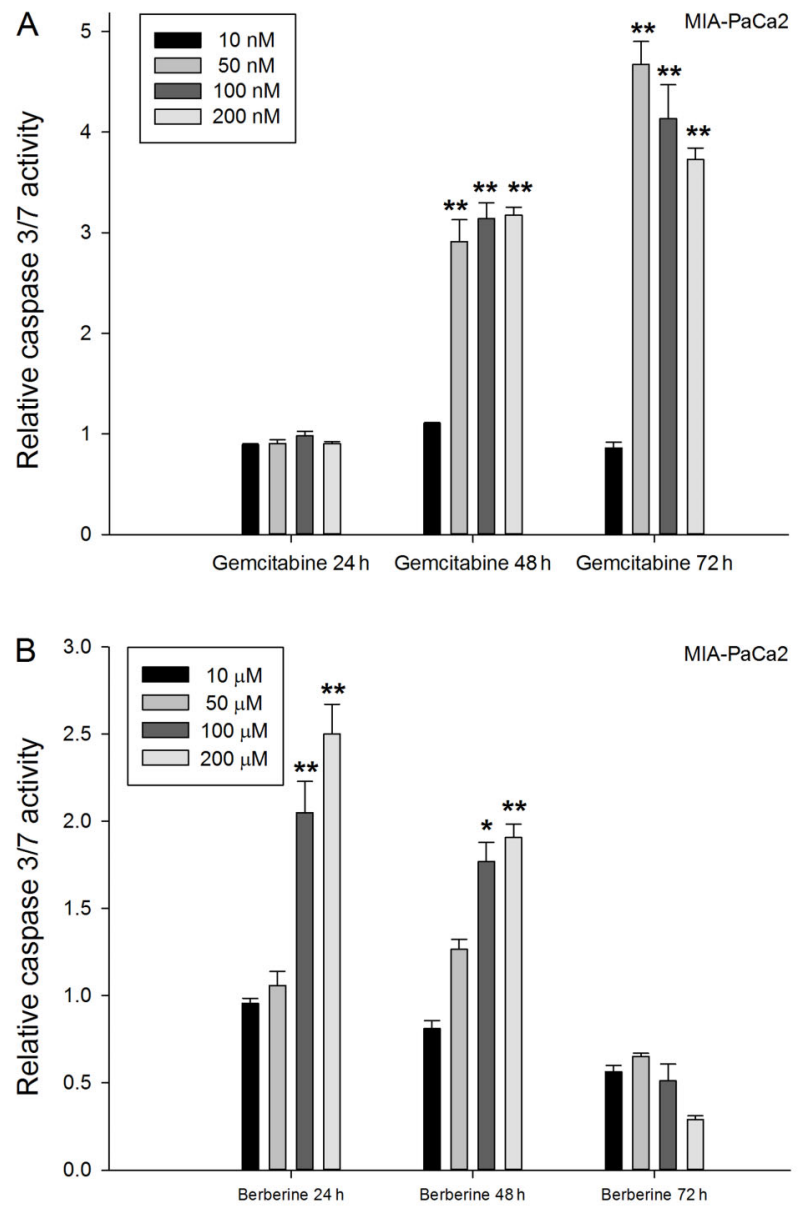

Figure 7. $A$, Caspase $3 / 7$ activity after treatment of MIA-PaCa2 cells with gemcitabine $(A)$ and berberine $(B)$ for 24,48 , or $72 \mathrm{~h}$. Data are reported as means $\pm S D$ activity $(n \geqslant 3)$ relative to control. ${ }^{*} \mathrm{P}<0.05,{ }^{* *} \mathrm{P}<0.01$ versus control (Student's $t$-test).

was also observed following treatment for 24 and $48 \mathrm{~h}$. When treated with the same concentration for the same amount of time, the overall ROS level in PANC-1 cells was higher than that in MIA-PaCa2 (data not shown).

\section{Discussion}

The poor prognosis for pancreatic cancer underscores the need to identify new therapeutic agents and targets. Recent studies have shown that berberine exerts a variety of pharmacological effects and contributes to the inhibition of cell proliferation of a variety of cancers (11-15). Here, we tested its anticancer effects in PANC-1 and MIA$\mathrm{PaCa} 2$ human pancreatic cancer cells.

Berberine significantly inhibited the proliferation and reduced the viability of PANC-1 and MIA-PaCa2 cells. These results suggest that berberine may be an effective chemotherapeutic agent for pancreatic cancer. The
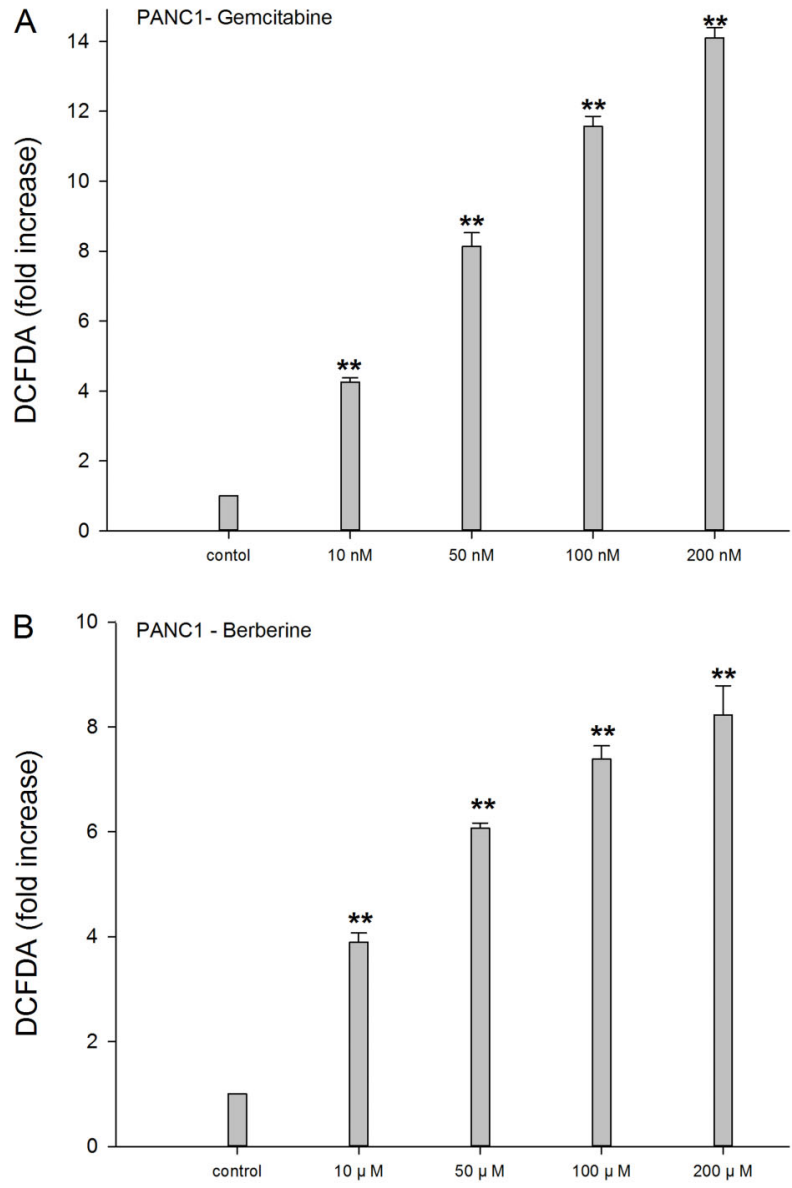

Figure 8. Intracellular reactive oxygen species (ROS) levels after 72-h gemcitabine $(A)$ and berberine $(B)$ treatment. Data are reported as means $\pm S D$ activity $(n \geqslant 3)$ relative to control. DCFHDA: $2^{\prime}, 7^{\prime}$-dichlorofluorescein diacetate. ${ }^{* *} \mathrm{P}<0.01$ versus control (Student's $t$-test).

inhibitory effect of berberine on pancreatic cancer cells was also due to its ability to induce cell cycle arrest. Whereas $\mathrm{G} 1$ arrest was induced with berberine treatment, arrest in the $S$ phase was induced when PANC-1 cells were treated with gemcitabine for $72 \mathrm{~h}$. The same results were obtained with MIA-PaCa2. Collectively, these results suggest that berberine inhibits pancreatic cancer cell proliferation by inducing G1-phase cell cycle arrest. These results are in agreement with various studies that treated other cancer cell lines with berberine. It has been reported that berberine inhibits growth by inducing G1-phase arrest in cholangiocarcinoma cells, prostate cancer cells, and lung cancer cells; berberine also inhibits cell growth by causing G2/M-phase arrest in prostate cancer cells (10,16-18).

The G1 phase can allow cells to induce repair mechanisms or apoptotic pathways. Thus, the effects of 
berberine on apoptosis induction of PANC-1 and MIA$\mathrm{PaCa} 2$ cells were determined, and the results indicated that treatment of pancreatic cancer cells with berberine effectively induced apoptosis, as has been observed for breast cancer, prostate cancer, and colorectal cancer cells $(10,19-21)$. A recent study reported that berberine efficiently suppresses cancer stem cells (22). In particular, the current results indicated that berberine had a greater apoptotic effect in PANC-1 cells than did gemcitabine, which is considered the standard treatment for pancreatic cancer. In some cancers, cells can become resistant to apoptosis and do not respond to chemotherapeutic agents (23). Thus, a variety of agents are useful, as long as they can induce apoptosis via either caspasedependent or caspase-independent pathways. Upon treatment of PANC-1 and MIA-PaCa2 for $72 \mathrm{~h}$ at $\mathrm{IC}_{50}$, the caspase $3 / 7$ activities were almost the same as in control cells. This effect of berberine has also been observed in another pancreatic cancer cell line, PxPC-3

\section{References}

1. Jemal A, Siegel R, Ward E, Hao Y, Xu J, Thun MJ. Cancer statistics, 2009. CA Cancer J Clin 2009; 59: 225-249, doi: 10.3322/caac. 20006 .

2. Wang SJ, Gao Y, Chen H, Kong R, Jiang HC, Pan SH, et al. Dihydroartemisinin inactivates NF-kappaB and potentiates the anti-tumor effect of gemcitabine on pancreatic cancer both in vitro and in vivo. Cancer Lett 2010; 293: 99-108, doi: 10.1016/j.canlet.2010.01.001.

3. O'Reilly EM, Abou-Alfa GK. Cytotoxic therapy for advanced pancreatic adenocarcinoma. Semin Oncol 2007; 34: 347353, doi: 10.1053/j.seminoncol.2007.05.009.

4. Burris HA III, Moore MJ, Andersen J, Green MR, Rothenberg ML, Modiano MR, et al. Improvements in survival and clinical benefit with gemcitabine as first-line therapy for patients with advanced pancreas cancer: a randomized trial. J Clin Oncol 1997; 15: 2403-2413.

5. Maitra A, Hruban RH. Pancreatic cancer. Annu Rev Pathol 2008; 3: 157-188, doi: 10.1146/annurev.pathmechdis.3. 121806.154305.

6. Bezakova L, Misik V, Malekova L, Svajdlenka E, Kostalova D. Lipoxygenase inhibition and antioxidant properties of bisbenzylisoqunoline alkaloids isolated from Mahonia aquifolium. Pharmazie 1996; 51: 758-761.

7. Misik V, Bezakova L, Malekova L, Kostalova D. Lipoxygenase inhibition and antioxidant properties of protoberberine and aporphine alkaloids isolated from Mahonia aquifolium. Planta Med 1995; 61: 372-373, doi: 10.1055/s2006-958107.

8. Chen J, Zhao H, Wang X, Lee FS, Yang H, Zheng L. Analysis of major alkaloids in Rhizoma coptidis by capillary electrophoresis-electrospray-time of flight mass spectrometry with different background electrolytes. Electrophoresis 2008; 29: 2135-2147, doi: 10.1002/elps.2007 00797.

9. Zhu XZ, Li XY, Liu J. Recent pharmacological studies on natural products in China. Eur J Pharmacol 2004; 500: 221230, doi: 10.1016/j.ejphar.2004.07.027.
(21). Our caspase $3 / 7$ assay results suggest that the mechanism for apoptosis was caspase 3/7-independent when berberine and gemcitabine are administered at $\mathrm{IC}_{50}$ values. However, at much higher concentrations, the relative caspase 3/7 activities increased several fold, indicating that apoptosis becomes caspase 3/7 dependent. Additionally, when the time courses of caspase $3 / 7$ activities were observed for both compounds, berberine activated caspase 3/7 activity before gemcitabine. Our study results are in agreement with previous findings that ROS production is increased in various cancer cells by treatment with anticancer drugs $(10,24,25)$.

\section{Acknowledgments}

This research was supported by the Korea Health Technology R\&D Project (\#B110053), Ministry of Health and Welfare and by a Korea University grant.

10. Mantena SK, Sharma SD, Katiyar SK. Berberine, a natural product, induces G1-phase cell cycle arrest and caspase-3dependent apoptosis in human prostate carcinoma cells. Mol Cancer Ther 2006; 5: 296-308, doi: 10.1158/15357163.MCT-05-0448.

11. Amin $\mathrm{AH}$, Subbaiah TV, Abbasi KM. Berberine sulfate: antimicrobial activity, bioassay, and mode of action. Can J Microbiol 1969; 15: 1067-1076, doi: 10.1139/m69-190.

12. Bova S, Padrini R, Goldman WF, Berman DM, Cargnelli G. On the mechanism of vasodilating action of berberine: possible role of inositol lipid signaling system. J Pharmacol Exp Ther 1992; 261: 318-323.

13. Akhter $\mathrm{MH}$, Sabir M, Bhide NK. Anti-inflammatory effect of berberine in rats injected locally with cholera toxin. Indian J Med Res 1977; 65: 133-141.

14. Lee YS, Kim WS, Kim KH, Yoon MJ, Cho HJ, Shen Y, et al. Berberine, a natural plant product, activates AMP-activated protein kinase with beneficial metabolic effects in diabetic and insulin-resistant states. Diabetes 2006; 55: 2256-2264, doi: $10.2337 / \mathrm{db06}-0006$.

15. Kong W, Wei J, Abidi P, Lin M, Inaba S, Li C, et al. Berberine is a novel cholesterol-lowering drug working through a unique mechanism distinct from statins. Nat Med 2004; 10: 1344-1351, doi: 10.1038/nm1135.

16. He W, Wang B, Zhuang $Y$, Shao D, Sun K, Chen J. Berberine inhibits growth and induces $\mathrm{G} 1$ arrest and apoptosis in human cholangiocarcinoma QBC939 cells. J Pharmacol Sci 2012; 119: 341-348, doi: 10.1254/jphs. 12052FP.

17. Wang Y, Liu Q, Liu Z, Li B, Sun Z, Zhou H, et al. Berberine, a genotoxic alkaloid, induces ATM-Chk1 mediated G2 arrest in prostate cancer cells. Mutat Res 2012; 734: 2029, doi: 10.1016/j.mrfmmm.2012.04.005.

18. Sung JH, Kim JB, Park SH, Park SY, Lee JK, Lee H-S, et al. Berberine decreases cell growth but increases the side population fraction of $\mathrm{H} 460$ lung cancer cells. J Korean Soc Appl Biol Chem 2012; 55: 491-495, doi: 10.1007/s13765 
-012-2119-0.

19. Kuo HP, Chuang TC, Tsai SC, Tseng HH, Hsu SC, Chen $Y C$, et al. Berberine, an isoquinoline alkaloid, inhibits the metastatic potential of breast cancer cells via Akt pathway modulation. J Agric Food Chem 2012; 60: 9649-9658, doi: 10.1021/jf302832n.

20. Tillhon M, Guaman Ortiz LM, Lombardi P, Scovassi Al. Berberine: new perspectives for old remedies. Biochem Pharmacol 2012; 84: 1260-1267, doi: 10.1016/j.bcp. 2012.07.018.

21. Pinto-Garcia L, Efferth T, Torres A, Hoheisel JD, Youns M. Berberine inhibits cell growth and mediates caspase-independent cell death in human pancreatic cancer cells. Planta Med 2010; 76: 1155-1161, doi: 10.1055/s-0030-1249931.

22. Park SH, Sung JH, Chung N. Berberine diminishes side population and down-regulates stem cell-associated genes in the pancreatic cancer cell lines PANC-1 and MIA PaCa-2. Mol Cell Biochem 2014; 394: 209-215, doi: 10.1007/s11010014-2096-1.

23. Pilat MJ, Kamradt JM, Pienta KJ. Hormone resistance in prostate cancer. Cancer Metastasis Rev 1998; 17: 373-381, doi: 10.1023/A:1006166511344.

24. He C, Rong R, Liu J, Wan J, Zhou K, Kang JX. Effects of Coptis extract combined with chemotherapeutic agents on ROS production, multidrug resistance, and cell growth in A549 human lung cancer cells. Chin Med 2012; 7: 11, doi: 10.1186/1749-8546-7-11.

25. Eom KS, Kim HJ, So HS, Park R, Kim TY. Berberineinduced apoptosis in human glioblastoma T98G cells is mediated by endoplasmic reticulum stress accompanying reactive oxygen species and mitochondrial dysfunction. Biol Pharm Bull 2010; 33: 1644-1649, doi: 10.1248/bpb.33.1644. 